\title{
Transferred Tax Knowledge to Improve Taxpayer Compliance
}

\author{
Nurcahyaning Dwi Kusumaningrum ${ }^{1}$, Rachmat Hidayat $^{2}$, Galih Wicaksono ${ }^{3}$, Yeni Puspita ${ }^{4}$, \\ Venantya Asmandani ${ }^{5}$, Tree Setiawan Pamungkas ${ }^{6}$, Djoko Susilo ${ }^{7}$ \\ 1,3,4,5 Program Studi Perpajakan \\ 2,6 Program Studi Administrasi Negara \\ ${ }^{7}$ Jurusan Hubungan Internasional
}

Fakultas Ilmu Sosial dan Ilmu Politik, Universitas Jember, Jl. Kalimantan No. 37, Jember, Jawa Timur

E-mail: Nurcahyaning.fisip@unej.ac.id

$\begin{array}{ll}\text { ARTICLE INFO } & \text { ABSTRACT } \\ & \begin{array}{l}\text { The purpose of research to know the influence of the taxpayer science level on } \\ \text { the compliance of paying taxes by taxpayers, among others: knowledge of tax }\end{array} \\ \text { Article history: } & \begin{array}{l}\text { law, system knowledge and taxation functions, and the knowledge of sanctions } \\ \text { Received: } 25 / 01 / 2020\end{array} \\ \text { Revised: } 01 / 02 / 2020 & \begin{array}{l}\text { Taxation both partially and simultaneously. Data analysis methods use SPSS } \\ \text { softwith a linear regression analysis, which is used to test the } \\ \text { hypothesized influence of the taxpayer's level of science to pay tax compliance } \\ \text { by both partial and simultaneous taxpayers and See the magnitude of the } \\ \text { coefficient. Based on the results the study concluded that in partial and } \\ \text { simultaneous levels of taxpayer enforcement science has a significant effect on } \\ \text { the compliance of paying taxes by taxpayers. } \\ \text { Keywords: }\end{array} \\ \text { Transferred Knowledge, } & \end{array}$

\section{Introduction}

According to Act No. 28 of the year 2007 article 1 paragraph 1, the tax shall be the mandatory contribution to the country owed by the person who is a force or entity that is forced under the law by not obtaining direct remuneration and use for the country's prosperity as a whole. Hidayat said Good governance in the decentralization era in Indonesia calls for the urgency of implementing Total Quality Management across various public service activities at the regional level. In this era, local governments denote the spearhead of increasing the quality of local government public services (Susilo, D., R. Hidayat, et al.,2018). Income derived from taxes can be felt by the people for the prosperity of the people, one of which is public service. Following LAW No 25-year 2009, public service is interpreted as activities or series of activities in the effort to fulfill the needs of services following the legislation for each citizen for goods and services, or administrative services provided by public service providers. One of the Government's efforts to improve public services is that the government is innovating to improve the quality of service to the public/society based electronically. According to the tax collectors divided into 2 (two) types, namely the central tax and local taxes. The local tax is divided into 2 (two) types of collectors, namely district and provincial tax. District/city tax e.g. restaurant tax, Hotel tax, entertainment tax, and street lighting tax. As for the provincial tax e.g. motor vehicle tax and motor vehicle fuel tax.

Government has a role in managing public finances (Boedijono, et al, 2019). One of the Government's efforts to increase the regional genuine income (PAD), the governments of each province should innovate to be more effective and efficient. The central government has created a new program to increase the original revenue of the area called e-filling. E-filling is a means of delivering SPT or annual SPT renewal notice conducted online and in real-time through the website e-filing tax ĐP Online or the application provided by ASP (application Service Provider/Application Service Provider) tax (online-pajak.go.id, 2019). According to Nurlaela (2018), This e-filling is deliberately made so that there is no taxable contact with the tax authorities and the taxpayer control can be high because of recording its SPT. E-filling aims to achieve transparency and can eliminate the practices of corruption, collusion, and nepotism (KKN). This e-Filling Program is implemented starting from 2007 and used for taxpayers throughout Indonesia which aims to facilitate and accelerate the annual tax reporting, and in the year 2007 is still not effective done by

Accredited "Rank 4"(Sinta 4), DIKTI, No. 36/E/KPT/2019, December 13"th 2019. 


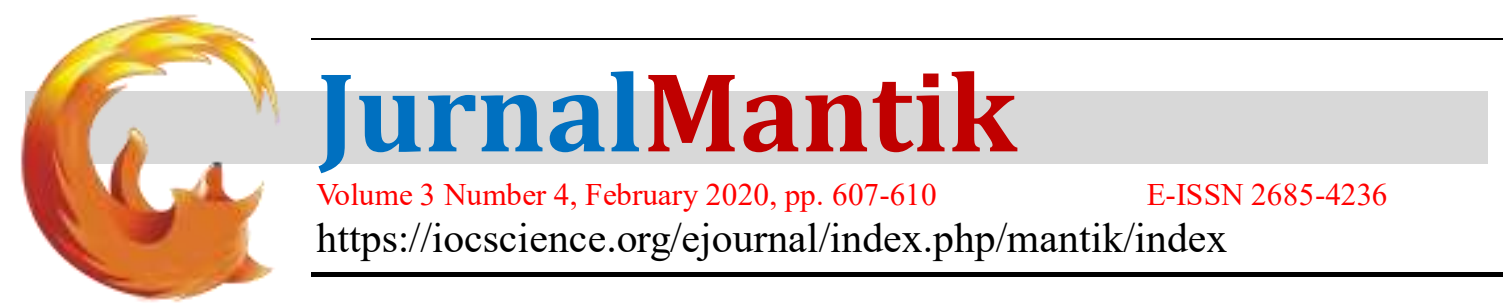

all taxpayers one of the factors is the difficulty of some areas affordable internet and public ignorance of the program so that public difficulties to conduct annual tax reporting. According to Chalik, I.A. (2017) efilling still there are shortcomings and there are still many things to be understood related to the readiness of human resources, facilities and supporting devices so that for a maximum application it takes a long enough time. The problem of taxpayer knowledge level will be the online system of e-filling will affect tax acceptance and compliance in paying, and report taxes. The level of knowledge of taxation is everything that is known to be taxpayers in taxation regulations whether it is about tax rates based on the laws that they will submit as well as the tax benefits used as a public interest. According to Septiana, L. (2016) knowledge can be classified into three, namely procedural knowledge, declarative knowledge, and knowledge of tacit (tacit knowledge). Based on the phenomenon, the problem formulation in the research to know the influence of the taxpayer knowledge on taxpayer compliance.

\section{Literature Review}

\subsection{Transferred Knowledge}

Tax knowledge is tax information that can be used taxpayers as a basis for acting, making decisions, and to pursue certain directions or strategies with the implementation of its rights and obligations in the taxation field (Ilhamsyah, R ., 2016). Taxknowledgeisused by taxpayers to make decisions in determining the strategy for carrying out its rights and obligations in the tax sector. Based on the concept of knowledge or understanding of tax according to Rahayu, N. (2017), taxpayers must include knowledge about the general provisions and procedures of taxation, the taxation system in Indonesia, and taxation function.

\subsection{Taxpayer Compliance}

Nurmantu in Wayan, H. U., \&Ayuni, N. W. D. (2019), explained that there are two kinds of obedience namely: (1) formal compliance. Formal compliance is a condition where the taxpayer satisfies the formal taxation obligations following The provisions of the taxation law. In this case, formal compliance includes (a) The taxpayer pays the tax promptly; (b) The taxpayer pays the appropriate tax amount; (c) The taxpayer does not have the Earth and building tax liability. (2) Material compliance. Material compliance is a condition where the taxpayers are substance or in essence fulfilling all taxation provisions, namely following the contents and souls of taxation laws. The definition of material compliance, in this case, is: (a) taxpayers are willing to report information about taxes when officers need information; (2) The taxpayer is cooperative (not troublesome) tax officer in the implementation of taxation administration; Taxpayer believes that carrying out tax obligations is an act as a good citizen. Furthermore, according to Rahayu, N. (2017), tax compliance can be defined as "a state where taxpayers meet all tax obligations and enforce its tax rights." There are two kinds of tax compliance, namely formal compliance, and material compliance.

\subsection{Hypothesis}

In connection with the problem of taxpayer knowledge level will be the online system of e-filling will influence the tax acceptance and compliance in the pay, and report taxes. Based on the background of the issue and literature review, this research hypothesis is as follows:

H : Transferred Tax knowledge level has a significant effect on taxpayer compliance

\section{Research Method}

Quantitative research instruments use methods conducted by Ghozali, Imam (2016) using questionnaires containing questions that measure respondents ' perception of proposed research variables. Questionnaires are distributed to the respondents which are taxpayers of motor vehicles, so it will be appropriate. Once collected, this questionnaire will be processed and analyzed quantitatively using SPSS software.

In this study there were two kinds of variables, i.e. dependent variables or bound variables, and independent variables or free variables, with the following description:
1. Dependent Variable
$\mathrm{Y}$ : Taxpayer compliance
2. Independent Variable
$\mathrm{X}$ : Transferred Knowledge 


\section{Results and Discussion}

\section{a) Descriptive Statistic Analysis}

Table 1.

Statistic Descriptive

\begin{tabular}{cccccc}
\hline Variable & N & Minimum & Maximum & Mean & Std. Deviation \\
\hline Transferred Knowledge & 125 & 14 & 50 & 43,14 & 6,679 \\
\hline Taxpayer Compliance & 125 & 16 & 45 & 39,06 & 5,733 \\
\hline
\end{tabular}

Source: Data processed,2020

From the descriptive statistics table, it is known that the sample amount for the entire variable is 125 . The smallest rate data is 14 , the largest data is 50, the mean of 43.14 and the standard deviation of 6.679. The smallest taxpayer compliance data is 16 , the largest data is 45 , the mean of 39.06 , and the standard deviation of 5.733

\section{b) Partial Test} variables.

This hypothesis test aims to test the significance of the influence between variables free of its

Table 2.

Partial Test ( T Test)

\begin{tabular}{ccc}
\hline Variable & T & Significant \\
\hline $\begin{array}{c}\text { Transferred Knowledge level }(\mathrm{X}) \text { to } \\
\text { taxpayers ' compliance }(\mathrm{Y})\end{array}$ & 12,022 & 0,00
\end{tabular}

Source: Data processed,2020

Based on the results of a partial test of the influence of knowledge level compliance with the taxpayer using the program SPSS obtained Thitung of 12.022 with the significance of 0.000 . The significance value of 0.000 is smaller than 0.05 . This indicates that at a rate of the significance of $5 \%$, the level of enforcement has a positive and significant influence on taxpayer compliance. With increasing levels of knowledge will be followed by increasing taxpayers ' compliance. The results of this research are in line with the research of Randi et al. (2016), Rahayu (2017), and Nugroho (2016) stating that the level of taxation knowledge influences taxpayer compliance.

\section{c) Simultaneous Test}

These tests to test the simultaneous influence of working capital turnover, liquidity, cash turnover, receivables turnover, inventory turnover, cash versus total assets to profitability.

Table 3.

Simultaneous Test (F Test)

\begin{tabular}{cccc}
\hline Variable & df & F & Significant \\
\hline $\begin{array}{c}\text { Level of knowledge towards } \\
\text { taxpayer compliance }\end{array}$ & 1 & 144,539 & 0,000 \\
\hline Source: Data Processed & 2020 & & \\
\hline
\end{tabular}

Source: Data Processed, 2020

F test results obtained an F value count of 144.539 with a probability 0.000 . Since the knowledge level is much smaller than 0.05 , then regression models can be used to predict taxpayers ' compliance. Therefore, it can be said that the level of knowledge has a significant effect on taxpayers ' compliance.

\section{Conclusion}

Based on the results of the study and the discussion can be concluded that from 125 respondents in the data are found results of quantitative data using partial regression partially and simultaneously the level of knowledge is significant to Taxpayer compliance of 0.000 . With increasing levels of knowledge will be followed by increasing taxpayers ' compliance. The results of this research are in line with the research of Randi et al. (2016), Rahayu (2017), and Nugroho (2016) stating that the level of taxation knowledge influences taxpayer compliance. 


\section{Reference}

[1] Boedijono, Wicaksono, G, \& Puspita, Y et al. (2019). EFEKTIFITAS PENGELOLAAN DANA DESA UNTUK PEMBANGUNAN DAN PEMBERDAYAAN MASYARAKAT DESA DI KABUPATEN BONDOWOSO. Jurnal Riset Manajemen dan Bisnis (JRMB) Fakultas Ekonomi UNIAT, 4(1), 9 - 20

[2] Chalik, I. A. (2017). Analisis Faktor-Faktor yang Berpengaruh terhadap Minat Pengguna E-Filling. Jurnal Aplikasi Manajemen, Ekonomi dan Bisnis, 2(1), 94-101.

[3] Ghozali, Imam. 2016. Aplikasi Analisis Multivariate Dengan Program SPSS. BP Undip, Semarang.

[4] Ilhamsyah, R. (2016). "Pengaruh Pemahaman dan Pengetahuan Wajib Pajak Tentang Peraturan Perpajakan, Kesadaran Wajib Pajak, Kualitas Pelayanan, dan Sanksi Perpajakan Terhadap Kepatuhan Wajib Pajak Kendaraan Bermotor (Studi SAMSAT Kota Malang)." Jurnal Mahasiswa Perpajakan $8(1)$.

[5] Nugroho, A., R. Andini, et al. (2016). "Pengaruh kesadaran wajib pajak dan pengetahuan perpajakan wajib pajak terhadap kepatuhan wajib pajak dalam membayar pajak penghasilan (studi kasus pada KPP Semarang Candi)." Journal Of Accounting 2(2).

[6] Nurlaela, L. (2018). Pengaruh Penerapan E-Filing Terhadap Kepatuhan Wajib Pajak Pada KPP Pratama Garut. Journal Wahana Akuntansi, 2(2), 1-8.

[7] Rahayu, N. (2017). "Pengaruh pengetahuan perpajakan, ketegasan sanksi pajak, dan Tax amnesty terhadap kepatuhan wajib pajak." Akuntansi Dewantara 1(1): 15-30.

[8] Septiana, L. (2016). Perancangan Sistem Pakar Diagnosa Penyakit Ispa Dengan Metode Certainty Factor Berbasis Android. Jurnal Techno Nusa Mandiri, 13(2), 89-96.

[9] Susilo, D., Hidayat, R., Pamungkas, T. S., Wicaksono, G., Kusumaningrum, N. D., \& Asmandani, V. (2018). Total Quality Management On One-Stop Integrated Licensing Service In Indonesia: A Study Of Two Regional Governments In East Java. Int J Recent Sci Res. 9(12), pp.89-96.30122-30126

[10] Undang Undang, R. (2017). "Nomor 28 Tahun 2007, Tentang Ketentuan Umum Dan Tata Cara Perpajakan."

[11] Undang Undang, R. (2017). "Nomor 25 Tahun 2009, Tentang Pelayanan Publik."

[12] Wayan, H. U., \&Ayuni, N. W. D. (2019). Pengaruh Tax Amnesty pada Kepatuhan Wajib Pajak Sektor Industri Pariwisata di Bali. Jurnal Bisnis dan Kewirausahaan, 15(1),22-30. 